\title{
Objektivní poznání v kontextu naturalizace filosofie
}

\author{
Jitka Paitlová - Petr Jedlička \\ Západočeská univerzita v Plzni, CZ
}

\begin{abstract}
PAITLOVÁ, J. - JEDLIČKA, P.: Objective Knowledge in the Context of Naturalization of Philosophy.

Philosophica Critica, vol. 6, 2020, no. 1, ISSN 1339-8970, pp. 37-51
\end{abstract}

In the paper, we analyze several key philosophical approaches to objective knowledge (Descartes, Kant), which we described as "speculative", that is theoretical and independent of experience. Our interpretation is based on the argument that the demarcation between speculative philosophy and empirical science (which is at the same time the boundary of objective knowledge) has been gradually reduced and that philosophy has been naturalized. We claim that Popper's transcendental thesis was extended by Quine and his appeal to the naturalization of philosophy, and Bloor accepted naturalism as one of the premises for his sociology of scientific knowledge. The culmination of this tendency is in empirical and experimental philosophy. In conclusion, we will introduce experimental philosophy, which has developed significantly in recent years, as one of the ways how to approach the question of "objective knowledge" by combining speculative approaches and empirically acquired data.

Key words: Objective knowledge - Naturalism - Kant - Popper Quine - Experimental philosophy

\section{Úvod}

Problém objektivního poznání byl v dějinách filosofie diskutován z různých úhlů pohledů již nesčetněkrát a tradiční filosofie zahrnuje dokonce mnoho místy divergentních přístupů $\mathrm{k}$ tomuto problému. $\mathrm{V}$ této stati se nejprve zaměříme právě na rozbor různorodosti dvou klíčových klasických novověkých př́stupů Descarta a Kanta, které označíme jako „spekulativní“, to 
znamená: teoretické úvahy nezávislé na empirickém zkoumání. ${ }^{1}$ Poté obrátíme pozornost na tři vybrané přístupy filosofů vědy minulého století, tj. Poppera, Quina a Bloora, kteří nejenže každý svým způsobem přispěli k diskuzi o objektivním poznání, nýbrž nadto jejich koncepce vykazují postupný odklon od Kantovy demarkace mezi filosofií a vědou, což označíme za trend „naturalizace“ filosofie. Naším záměrem není všeobsáhlý výklad problému objektivního poznání, ani podrobný výklad jednotlivých vybraných koncepcí. Cílem této stati je právě naznačení specifického trendu naturalizace ve filosofii, který se stal pro význam objektivního poznání do značné míry určující. Zaměříme se zejména na filosofii vědy, neb právě s vědou je objektivní poznání spojováno prioritně. ${ }^{2}$

Náš výklad bude spočívat na argumentu, že původně Immanuelem Kantem vymezená demarkace mezi spekulativní filosofií a empirickou vědou, která představuje zároveň hranici objektivního poznání skutečnosti, byla postupně redukována, nebot' filosofie vědy se - u některých myslitelů - v průběhu 20. století, na které se zaměříme, výrazně naturalizovala. Právě na příkladu vybraných „naturalizovaných“ př́ístupů k objektivnímu poznání či „objektivitě“ budeme tvrdit, že Willard Quine svým apelem na naturalizaci filosofie ještě více vyostřil původní transcendentální tezi Karla Poppera a David Bloor přijal naturalismus jako jeden z hlavních předpokladů své sociologie vědeckého poznání. Za vyvrcholení této tendence pak označíme takzvanou empirickou a experimentální filosofii, která se od počátku 21. století významně rozvíjí a ukazuje se být jedním ze způsobů, jakým je možné přistupovat k problému objektivity a objektivního poznání na základě kombinace spekulativních přístupů i empiricky získaných dat.

\section{Proměna chápání objektivního poznání v novověku}

Pojem „objektivita“ se jeví být moderním pojmem, avšak vývoj tohoto konceptu sahá hlouběji do historie. Souhlasíme s Dastonovou a Gallisonem, kteří tvrdí, že „dějiny objektivity jsou jen podmnožinou mnohem delších a rozsáhlejších dějin teorie poznání, to znamená filosofického zkoumání překážek, které se staví na odpor poznání a vědění" (Daston - Gallison 2007, 29). Adjektivum „objektivní“ (lat. objective) zavedli do filosofie již ve 14. století scholastikové Duns Scotus a William Ockham, avšak ve zcela odlišném významu, než jak jej chápeme dnes: „Od samého počátku byl

\footnotetext{
1 V současné literatuře lze najít též označení „a priori philosophy“, tzn. apriorní filosofie nebo „armchair philosophy“, tzn. filosofie dělaná z křesla, viz níže.

2 Přitom se úmyslně vyhneme kritickým postojům vůči „objektivizaci“ či „Zvěcňování“ poznání, na níž poukazují zejména různí představitelé kontinentální filosofie (jako např. fenomenologie, hermeneutika, kritická teorie etc.).
} 
[pojem obiectivus/obiective] vždy spárován se subiectivus/subiective, ale ty pojmy původně znamenaly skoro přesný opak toho, co znamenají dnes. ,Objektivní odkazovalo k věcem, které jsou předkládány vědomí, zatímco ,subjektivní odkazovalo k věcem samým o sobě" (Daston \& Gallison 2007, 29).

Tento scholastický význam lze nalézt ještě u Descarta, který rozlišuje „formální realitu“ našich myšlenek, tj. nakolik odpovídají něčemu ve vnějším světě, s jejich „objektivní realitou“, tj. míru skutečnosti, kterou mají z hlediska pravidla jasnosti a rozlišenosti, jež ovšem naplňují i ideje (např. idea Boha) bez ohledu na to, zda jim odpovídají hmotné předměty. René Descartes v Meditacích o první filosofii (1641) skutečně přisuzuje „objektivní realitu“ (realitatis objectivae) ideji nanejvýš dokonalého jsoucna. ${ }^{3}$ Proto pojem „objektivní - v českém překladu „předmětný“ - používá Descartes zejména v důkazu boží existence ve III. Meditaci:

„Ideje, jež mi ukazují substance, jsou totiž bezpochyby něčím větším a obsahují v sobě takříkajíc více předmětné reality [realitatis objectivae] než ideje, které reprezentují pouhé mody či akcidenty; a idea, skrze niž chápu nějakého nejvyššího Boha, věčného, nekonečného, vševědoucího, všemohoucího a stvořitele všech věcí, které kromě něho jsou, má pak v sobě rozhodně více předmětné reality než ideje, skrze něž se ukazují konečné substance. [...] Nelze říci, že je snad tato idea Boha materiálně nepravdivá, a může být proto od ničeho [...]: právě naopak, když je naprosto jasná a rozlišená a obsahuje více předmětné reality než kterákoli jiná, žádná idea není o sobě pravdivějšíi“ (Descartes 2003, 40, 45).

Pojem „objektivní“ spojuje Descartes s epistemologickou jasností a rozlišeností ideje Boha jako „nekonečné substance“, což ji činí pravdivější a objektivnější než cokoli jiného. Kvalita „objektivní“ proto souvisí s pravdou, která je dána pravidlem clare et distincte a náleží u Descarta více idejím než smyslové zkušenosti - $\mathrm{v}$ hierarchii od ideje nekonečné substance Boha, přes konečnou substanci myslící (res cogitans), po substanci tělesnou (res extensa). Descartes tedy vymezil objektivní poznání pozitivně, když je spojil s pravdou, jež je dána pravidlem jasného a rozlišeného, avšak náleží ve větší míře abstraktním idejím než smyslové empirii. Ačkoli se tedy u Descarta vztahuje pojem objektivní k pravdivému poznání dokonalého jsoucna, toto jsoucno je z empirického pohledu nedokazatelné, a proto bychom ho dnes za objektivní zřejmě neoznačili.

Viz latinský text Meditací podle Adama a Tanneryho, s. [14], dostupné na www: http://www.thelatinlibrary.com/descartes/des.syn.shtml 
Uvedená Descartova interpretace v souvislosti s objektivitou poznání je ovšem spíše intenční vzhledem k důkazu boží existence. Podrobný rozbor problému objektivního poznání provedl až Immanuel Kant, který se snažil vyřešit problém slučitelnosti newtonovské fyziky s leibnizovskou metafyzikou, a tak si položil otázku, jak je možné myslet spojení empirické a inteligibilní skutečnosti, tj. výchozí otázka Kritiky čistého rozumu (1787): „Jak jsou možné syntetické soudy a priori?“ (B 19) ${ }^{4}$ Kant chtěl tuto otázku zodpovědět na základě určení podmínek čisté vědy jakožto podmínek poznání veškeré možné zkušenosti. Z hlediska empirického, tedy „co do času v nás žádné poznání zkušenost nepředchází, a všechno poznání zkušeností začíná“ (B 1). Z hlediska apriorního však podle Kanta existuje „poznatek, nezávislý na zkušenosti“ (B 2). V souvislosti s tím, je i objektivita poznání vázaná jednak empiricky na předmět (tj. na zkušenost), jednak a priori na možnost zkušenosti (je dána apriorními formami poznání):

„Má-li mít nějaký poznatek objektivní realitu, tj. má-li se vztahovat $\mathrm{k}$ nějakému předmětu a jeho prostřednictvím získat význam a smysl, musí být možné, aby byl předmět nějakým způsobem dán. [...] Možnost zkušenosti je tedy tím, co všem našim poznatkům apriorně dává objektivní realitu" (B 194-195).

Objektivní poznání má proto u Kanta empirickou i apriorní dimenzi. Cílem Transcendentální logiky je určit „vznik, rozsah a objektivní platnost“ poznatků a priori (B 81). Směrodatné je Kantovo tvrzení, že „pouhá forma poznatku, at' se sebevíce shoduje s logickými zákony, ani zdaleka nestačí zajistit poznatku materiální (objektivní) pravdivost" (B 85). ${ }^{5}$ Zde je zvýrazněna první dimenze Kantova chápání pojmu „objektivní“ ve významu „materiální“ a „empirický“. Jinými slovy: má-li mít nějaký poznatek objektivní realitu, musí se vztahovat k nějakému předmětu (ve zkušenosti). Proto pouhá logická možnost nemůže být objektivní, pokud se nevztahuje na určitý předmět. Nicméně ačkoli „představa sama o sobě svůj předmět co do existence nevytváří, přesto je vzhledem k předmětu a priori určující, nebot' jedině skrze ni lze poznat něco jako předmět" (B 125). To vyjadřuje druhou, apriorní dimenzi významu pojmu objektivní. K empirické realitě totiž patří i to, že předmět má nějaký význam a smysl, což je umožněno apriorními formami smyslovosti (prostor a čas) a zejména rozvažování (kategorie).

U Kantovy Kritiky čistého rozumu je vždy v závorce použita klasická paginace (B), překlad viz seznam literatury: Kant (2001).

5 Kant obhajuje objektivní realitu vnějšího názoru. Srov. B 273: „To, že [čistý] pojem předchází [a priori] vjemu, znamená totiž jeho pouhou možnost; ale vjem, který poskytuje k pojmu látku, je jediným znakem skutečnosti“ Kant (2001). 
„Existují dvě podmínky, za nichž je jedině možné poznání nějakého předmětu: za prvé názor, jímž je tento předmět - ale pouze jako jev - dán, za druhé pojem, jímž je předmět, který tomuto názoru odpovídá, myšlen“ (B 125).

Již u Kanta tedy nalezneme základní definici pojmu objektivní ve smyslu „vztahovat se k nějakému předmětu“, který je popsatelný přírodními zákony (B 194). Důležitý je přitom fakt, že objektivní platnost (tedy objektivitu) určitému poznatku uděluje poznávající subjekt. Kant přitom jednoznačně ustanovil vztah a zároveň demarkační rozdělení kompetencí mezi filosofií a vědou. Zaprvé, oblastí metafyziky jsou rozumem myslitelné principy a ideje přesahující hranice zkušenosti, které si nemohou nárokovat objektivní platnost; zadruhé, předměty přírodních věd mohou být (díky a priori daným formám) poznány s objektivní platností, avšak nesmí překročit možnou zkušenost. Tím Kant explicitně spojil objektivitu právě s př́rodními vědami a empirickou skutečností a zároveň naznačil, že je to lidským poznáním ustavovaná hodnota. Kant jasně ř́ká, že filosofie má co dělat s transcendentálním zdáním a musí si toho být kriticky vědoma, nebot' ideje mají pouze regulativní funkci, nikoli konstitutivní: „transcendentální používání rozumu není vůbec objektivně platné, a tudíž nepatří k logice pravdy“ (B 170). Pohybujeme-li se naopak v oblasti možné zkušenosti, pak se podle Kanta pohybujeme v oblasti „logiky pravdy“, čímž je umožněna empirická objektivita přírodních věd (B 87). Ačkoli tedy Kantův přistup označíme za ryze spekulativní, tedy že pojednávající daný problém výhradně na základě teoretické úvahy, zároveň byl dostatečně kritický a na dlouhou dobu stanovil význam objektivního poznání.

\section{Objektivní poznání a naturalizace filosofie ve 20. století}

Substantivum „objektivita“ se podle Dastonové a Galisona definitivně etablovalo $\mathrm{v}$ polovině 19 . století, a to především v souvislosti s přírodními vědami, kdy se objektivita se stala jednou $\mathrm{z}$ „epistemických ctností“ vedle pravdy, jistoty, přesnosti a replikovatelnosti, jež od té doby tvoří étos moderních přírodních věd (Daston - Gallison 2007, 27-33). Tyto vědecké ctnosti v čele s objektivitou se postupně stále ostřeji distancovaly od subjektivity, došlo k oddělení mezi věděním a vědoucím s cílem potlačení (či nejlépe úplné eliminace) subjektivity. Ve filosofii druhé poloviny 19. století nastolili dichotomii mezi „objektivními“, př́rodovědnými a „subjektivními“, duchovědnými metodami zejména novokantovci Wilhelm Windelband a Heinrich Rickert. ${ }^{6}$ Objektivita, pravda a jistota se postupně staly příznačné právě pro přírodní vědy, což se odrazilo i ve filosofii,

6 Srov. (Holzhey - Röd 2006, 129, 138). 
zejména v pozitivismu, a později v logickém pozitivismu, kritickém racionalismu a některých dalších proudech analytické filosofie. Vlivný rozbor metod empirických věd představil Karl Popper ve spise Logika vědeckého zkoumání (1934), kde navrhuje koncepci objektivity, která se vztahuje primárně na vědecké teorie:

„Tvrdím, že vědecké teorie nejsou nikdy plně odůvodnitelné nebo verifikovatelné, ale že jsou nicméně testovatelné. Budu tudíž ríkat, že objektivita vědeckých tvrzení spočívá ve faktu, že mohou být intersubjektivně testována" (Popper 1997, 24).

V obecné rovině chápe Popper objektivitu jako metodologické pravidlo, tedy jako správný způsob testování vědeckých tvrzení (s vyšší mírou univerzálnosti), a to na základě testování jednotlivých důsledků (s nižší mírou univerzálnosti), které z těchto tvrzení vyplývají. Svoji koncepci objektivity navíc rozšíril i na sociální vědy v článku Logika sociálních věd (1961), kde píše:

„Takzvaná objektivita vědy spočívá v objektivitě kritické metody; to znamená především $v$ tom, že žádná teorie není osvobozena od kritiky, a také v tom, že logické prostředky kritiky - kategorie logického sporu - jsou objektivní" (Popper 1989, 106).

Mimo jiné zde odmítá relativistický argument, že objektivita vědy závisí na objektivitě vědce, z něhož má vyplývat, že přírodní vědci jsou „objektivnější" než sociální vědci. Podle Poppera „objektivita vědy není individuální záležitostí různých vědců, nýbrž sociální záležitostí jejich vzájemné kritiky“, která se ve skutečnosti sestává z „přátelsko-nepřátelské dělby práce vědců“, to znamená jak z jejich spolupráce, tak též z jejich soupeření - a v tomto smyslu závisí objektivita na celé řadě společenských a politických vztahů, avšak směrodatné je, že právě tyto vztahy umožňují kritiku, která pak konstituuje objektivitu (Popper 1989, 112).

Ještě později, ve spise Objektivní poznání (1972), popisuje Popper poznání v objektivním smyslu na modelu tří světů. Objektivní poznání spojuje výhradně s takzvaným světem-3, což je svět logických a myšlenkových obsahů, který je svým způsobem nezávislý jak na světě- 1 tvořeném fyzikálními předměty, tak na světě-2 sestávajícím ze subjektivních obsahů našeho vědomí. Tuto poněkud kontroverzní teoretickou konstrukci lze chápat jako vrchol Popperova tažení na obranu objektivity: „Poznání v objektivním smyslu je poznání bez poznávajícího: To je poznání bez poznávajícího subjektu“ (Popper 1994a, 112). Jde o vyhraněnou objektivistickou pozici, která de iure připisuje světu-3 autonomní ontologický status, čímž ale de facto popírá realistický předpoklad jediné na nás nezávislé skutečnosti, 
kterou tvoří materiálně-fyzikální svět, v němž platí jednotné zákonitosti. Kritikové to označují za „přebujelou ontologii“ (Keuth 1978, 190) či za „postradatelnou a neudržitelnou konstrukci“ (Zimmer - Morgenstern 2011, 53).

Také Willard Van Orman Quine ve svém textu Hledání pravdy (1992) podobně jako Popper uznává, že především „požadavek intersubjektivity je to, co dělá vědu objektivní", nicméně neklade přitom důraz na intersubjektivní „falzifikaci“ hypotéz v kontextu vědecké metodologie, nýbrž na intersubjektivní „reifikaci“ (tj. zvěcnění) fyzikálních i abstraktních objektů v rámci jazyka vědy (Quine 1994, 12). Quine totiž tvrdí, že teprve „jazyk je místem, kde nastupuje intersubjektivita" (Quine 1994, 52). Dále ukazuje, že věda je založena na určité ontologii jako naší „sofistikované koncepci setrvalých a znovu se objevujících těles", jejich postupné systematizaci a rostoucí reifikaci, tedy ustanovování stále dalších „předmětů“, o kterých vytváŕíme reference - přitom nejde jen o fyzikální objekty, ale také o abstraktní objekty, jako např́klad čísla. Tím sice „reference a reifikace přispívají k propracované struktuře, která vztahuje vědu k její smyslové evidenci“, avšak podle Quina jsou ontologie i reference pouhé pomůcky:

„Alfou a omegou podniku, kterým je věda, je pravdivá věta, pozorovací a teoretická. Ty jsou propojeny strukturou, a předměty figurují jako pouhé uzly této struktury“ (Quine 1994, 32, 38).

Z toho Quine vyvozuje dva závěry:

„Objektivita našeho poznání vnějšího světa zůstává zakotvena v našem kontaktu s vnějším světem, tedy v našich neurálních vstupech a v pozorovacích větách, které jim odpovídají. [...] Naše ontologie, tak jako gramatika, je částí našeho vlastního konceptuálního př́spěvku k naší teorii světa" (Quine 1994, 43-44).

Navíc v behavioristickém smyslu tvrdí, že „V jazykovém významu není nic kromě toho, co se posbírá ze zjevného chování za pozorovatelných okolností“ (Quine 1994, 46). I přes svoji relativizaci ontologie Quine prohlašuje, že je nezvratně přesvědčen o existenci věcí okolo nás a označuje se za naturalistu. Naturalismus definuje jako „přiznání si skutečnosti, že určení a popis reality je možný jedině v rámci vědy samotné a nikoli v rámci nějaké předcházející filosofie“" (Quine 2006, 77). Podle Quina nemáme jinou možnost než být empiristy a epistemologii chápat jako počin v rámci přírodní vědy. Například Peregrin v této souvislosti zdůrazňuje Quinovo přesvědčení, že „náš svět je vyčerpávajícím způsobem popsatelný jazykem fyziky“ (Peregrin 2014, 201). Důraz na jazykovou podmíněnost 
objektivního poznání, z níž vycházel Quine, se ve druhé polovině 20. století transformoval ve zdůraznění sociálního charakteru objektivního poznání.

$\mathrm{V}$ anglosaské filosofii vědy v šedesátých letech proběhl spor, kdy filosofové jako Norwood Russell Hanson, Thomas S. Kuhn a Paul Feyerabend vystoupili proti logickému empirismu. V roce 1962 vyšel Kuhnův spis Struktura vědeckých revolucí, čímž započal takzvaný sociologický obrat v teorii vědy, který dal vzniknout novému směru, který se vymezoval vůči tradiční racionalistické filosofii vědy. Takzvaná sociologie vědeckého poznání si vytkla za cíl analýzu vědeckého poznání sociologickými metodami. Tyto tendence vyvrcholily v polovině sedmdesátých let formulováním silného programu sociologie vědeckého poznání Davidem Bloorem ve spise Knowledge and Social Imagery (1976). Jako cíl si Bloor vytkl „zkoumat a vysvětlit samotný obsah a povahu vědeckých poznatků" prostřednictvím metod sociologie, přičemž „veškeré znalosti, at’ už se jedná o empirické vědy nebo dokonce o matematiku, by měly být zpracovány jako materiály pro zkoumání" (Bloor 1991, 4). Např́íklad Benda identifikuje jako výchozí metodologický předpoklad zastánců sociologie vědy právě naturalismus, to znamená, že se k vědeckému poznání snaží přistupovat jako k „přírodnímu fenoménu“, čímž chtějí eliminovat veškeré předem dané předpoklady, zároveň ovšem akcentují sociální charakter vědeckého poznání, a to včetně poznání př́rodovědného (Benda 2011, 52). Výsledkem je pak sociologická teorie objektivity:

„Ideje poznání jsou založeny na společenských představách, logická nutnost je druh morální povinnosti a objektivita je společenský fenomén." (Bloor 1991, 157-158).

Neboli „objektivita je sociální“ (Bloor 1991, 165). Přístup sociologie vědy k objektivitě je možné chápat jako zcela neslučitelný s výše nastíněnou Popperovou definicí objektivity, která sociální faktory a osobní charakter vědce vylučuje, a Bloora pak lze odsoudit za vnášení relativismu a subjektivismu do teorie vědy. ${ }^{7}$ Tomu se však on sám brání:

„Kde stojí sociologie vědění s ohledem na skálu objektivity? Říká, že skutečné objektivní poznání je nemožné? Rozhodně ne. Co bylo navrženo v diskuzi o Fregem, byla např́íklad sociologická teorie objektivity. Pokud by byla objektivita považována za neexistující, nebylo by zapotřebí vytvořit teorii, která by jí odpovídala. Ani to není způsob, jak říci, že objektivita je iluzí. Je skutečná, ale její povaha je zcela odlišná od toho, co se dalo očekávat. To, co odmítá

Srov. též (Kuhn 2000). 
sociologický program, jsou jiné teorie objektivity, nikoli samotný fenomén" (Bloor 1991, 160).

Z jiného úhlu pohledu, tedy v linii od metodologické intersubjektivity vědeckého poznání (Popper) přes intersubjektivní jazykovou reifikaci vědeckých objektů (Quine) můžeme př́iklon ke zkoumání sociálního charakteru vědeckého poznání (Bloor) nahlížet i jako další krok v řešení daného problému a jako snahu o odkrytí dalších dimenzí objektivity. Zajímavé je, že sociologie vědění se nebojí přistupovat $\mathrm{k}$ tomuto problému empiricky. Bloor dokonce píše, že „hledání zákonů a teorií v sociologii vědy je ve svém postupu naprosto totožné s jakoukoli jinou vědou“" (Bloor 1991, 21). Na základě toho tvrdíme, že jde o výrazný posun směrem k empirizaci určité části filosofie. ${ }^{8}$

\section{Empirická a experimentální filosofie jako aktuální přístupy k objek- tivnímu poznání}

Až na sociologii vědění, všechny výše zmíněné přístupy více či méně zůstávají spekulativní, to znamená: vycházejí z teoretické úvahy. Jak jsme ukázali, tento př́stup jasně definoval Kant, když oddělil filosofická tázání od zkušenosti a definoval je jako přesahující veškerou možnou zkušenost. Tento pohled se podle našeho názoru stal východiskem Popperova demarkačního problému, ačkoli si Popper se vztahem filosofie a empirických věd neustále pohrával. Už ve svém prvním spise Die beiden Grundprobleme der Erkenntnistheorie (1930-3) totiž zformuloval takzvanou transcendentální tezi:

„Filosofie je teoretická věda, která se vztahuje k empirickým vědám stejným způsobem, jako se empirické vědy vztahují k empirické skutečnosti“ (Popper 1994, 7). ${ }^{9}$

Epistemologická tvrzení a pojmy musí být podle Poppera kriticky testovány reálnými postupy empirických věd. To pak znamená, že teorie poznání se vztahuje $\mathrm{k}$ př́rodním vědám analogicky, jako se prŕírodní vědy vztahují ke zkušenostnímu světu. $\mathrm{V}$ tom lze v určitém smyslu nalézt zárodek naturalizace filosofie. Dále tvrdíme, že Popperovu tezi svým výše zmíněným apelem na naturalizaci filosofie ještě více vyostřil Quine. A konečně Bloorův silný program sociologie vědeckého poznání, který přijal

8 Srov. (Collin 2011). Na druhou stranu stále existují filosofičtí obhájci objektivního poznání, kteří nadále používají tradiční ryze spekulativní přístup, srov. (Rescher 1997, Nozick 2001 a Collier 2003).

9 Popper to doplňuje tzv. empiristickou tezí: „O pravdivosti výpovědí o skutečnosti může rozhodnout pouze zkušenost“ (Popper 1994, 58). 
naturalismus jako jeden ze svých hlavních předpokladů, chápeme jako další krok daným směrem. Samozřejmě jsme si vědomi mnohých rozdílů mezi př́stupy Poppera, Quina a Bloora, nicméně lze u nich vysledovat popsaný trend vzrůstající naturalizace a empirizace filosofie vědy, kdy je Popperova transcendentální teze a Quinův naturalismus uváděn do filosofické praxe.

Na závěr proto nastíníme, jak lze k objektivitě přistupovat nespekulativně, tedy empiricky, ba dokonce experimentálně. Ačkoli zní „empirická/ experimentální filosofie" alespoň z kantovského pohledu jako protimluv, pokusíme se ukázat, že experimentálně filosofický př́istup může mít své výhody (a zároveň samozřejmě i limity). Prvním krokem k nespekulativnímu filosofickému přístupu je zmíněná sociologie vědy, která se zaměřovala zejména na sociální komponentu, jež determinují vědecké poznání. Druhým krokem je pak empirická filosofie, která se objevuje především v oblasti morální filosofie a filosofie mysli. Vyznačuje se obecným charakterem otázek a tím, že zohledňuje výsledky z různých oborů psychologie, neurověd, evoluční teorie, experimentální ekonomie a dalších vědeckých oblastí. Nicméně empiričtí filosofové stále ještě „dělají konceptuální analýzu ,v křesle' (armchair), aby uvedli nebo interpretovali empirické výsledky prvního řádu“ (Prinz 2008, 189). Jde tedy o pasivní reflexi výsledků empirických věd při řešení filosofických otázek.

Proto je dalším krokem přístup, který se etabloval před zhruba patnácti lety a označuje se jako experimentální filosofie neboli „X-phi“. Pro tento přístup je příznačné, že (aktivně) navrhuje vlastní experimenty, jejichž výsledky prrímo aplikuje na filosofické problémy a diskutuje o důsledcích těchto údajů pro filosofické debaty. Např́klad Sosa označuje x-phi explicitně za "naturalistické hnutí ve filosofii“, nebot’ x-phi se vymezuje vůči spekulativním (armchair) metodám, ale neodmítá je zcela (Sosa 2007, 99). Zakladatelé x-phi, Joshua Knobe a Shaun Nichols, ji vidí dokonce jako „návrat k tradičním filosofickým otázkám o lidských bytostech" a zdůrazňují kontinuitu s tradiční filosofií (Knobe - Nichols 2008, 3). Prinz dodává, že i experimentální filosofové používají konceptuální analýzu, ale je zde charakterizována jako empirická aktivita: „introspekce zaměřená na intuice“ (Prinz 2008, 198). Jiní autoři pak tvrdí to, co jsme naznačili i my, totiž že ve filosofii vždycky existovaly empirické a naturalistické př́stupy, ovšem „aplikace empirických metod experimentální filosofií je velmi selektivní činnost, která je zaměřena na velmi specifický předmět, a to na zkoumání intuice" (Grundmann - Horvath - Kipper 2014, 9).

Důležité je, že x-phi navrhuje vlastní filosofické experimenty, používá přitom empirické metody (většinou převzaté například ze sociologie, 
kognitivní psychologie, neurověd, behaviorální ekonomie apod.), přičemž si zpravidla klade specifické filosofické otázky. Knobe a Nichols v Manifestu experimentální filosofie píší:

„Experimentální filosofové provádějí experimentální zkoumání psychologických procesů souvisejících s lidskými intuicemi o centrálních filosofických otázkách." (Knobe - Nichols 2008, 3).

X-phi tedy používá kontrolované systematické experimenty k prozkoumání intuicí a konceptuálního uvažování lidí a zkoumá, co výsledky těchto experimentů znamenají pro tradiční filosofické debaty. Ústředním pojmem jsou intuice o morálních nebo epistemických soudech zejména ve folk psychology, tedy u obyčejných lidí (nefilosofü). Intuice lze definovat jako mentální stavy sui generis, v nichž se propozice zdá být pravdivá. V x-phi slouží takovéto intuice jako důkaz obsahu sdílených společných pojmů. Metodou, jak x-phi intuice zkoumá, je experimentální sběr odpovědí na otázku: Jak lidé běžně myslí? Tvrzení o intuicích jsou interpretovány jako jednoduché empirické, a tedy testovatelné předpovědi o tom, jak obyčejní lidé budou odpovídat, když jim budou prezentovány aktuální nebo hypotetické př́pady. ${ }^{10}$

Je třeba poznamenat, že x-phi není ani převládající, ani zcela jednotný proud ve filosofii. Lze například rozlišit experimentální restriktivisty, kteř́ omezují roli intuicí, protože intuice se podle nich mění prostřednictvím psychologických a sociálních okolností, které nesouvisejí s pravdou daných filosofických tezí a teorií. Dále existují experimentální analytici, kteří se zaměřují spíše na cíl pokračovat v tradičním filosofickém projektu konceptuální analýzy experimentálními prostředky. A konečně experimentální deskriptivisté se více zajímají o psychologické mechanismy a struktury, které jsou základem intuicí (např. se ptají na vliv našich normativních úsudků na naše úsudky o filosofických otázkách) (Grundmann - Horvath Kipper 2014, 16-34). Obecně lze přednosti a zároveň problematické aspekty x-phi shrnout následovně: Role intuicí v epistemické kazuistice je zajisté nepostradatelná, nicméně není jasné, jak velká jejich role vlastně je. Způsob, jakým mají intuice fungovat v epistemologii a ve filosofii obecněji, je obdobou způsobu, jakým má pozorování fungovat v empirické vědě (zde můžeme vidět explicitní snahu o naplnění zmíněné Popperovy transcendentální teze) (Grundmann - Horvath - Kipper 2014, 9).

Dále zde na jednu stranu vyvstává otázka, jak mohou intuice běžných lidí („folk“) dát odpovědi na filosofické otázky, když se filosofové ptají na otázky, kterým běžní lidé nerozumí - to, co nekompetentní uživatelé

10 Srov. (Kauppinen 2007). 
konceptu ř́kají o daném případě, nám neřekne nic o konceptu, který nás zajímá, protože nemají žádné relevantní pre-teoretické znalosti. ${ }^{11} \mathrm{Na}$ druhou stranu sofistikované intuice filosofư nemusí popisovat intuice dalších skupin lidí, nebot’ filosofové jsou skupina s velmi specifickou vzdělávací historií. A není také zřejmé, proč by filosofické intuice měly mít privilegované postavení. Některé pojmy, jež filosofové používají k vysvětlení, jsou navíc jen technické pojmy. Ale měli by znát i původní význam těchto pojmů ve smyslu, ve kterém jsou obecně používány, a v tomto smyslu by filosofové měli pracovat s koncepty obyčejných lidí v rámci folk psychology. ${ }^{12}$ Benefitem x-phi tak může být podložení filosofických teorií empirickými daty o rozšíření a původu intuicí jak mezi laiky, tak filosofy nebo jinými skupinami. ${ }^{13}$

Problém nekompetentních uživatelů či respondentů bývá spekulativními filosofy vůči x-phi často používán, například v oblasti x-phi výzkumu z oblasti filosofie vědy. Oponenti zastávající „spekulativní pozice tvrdí, že nezdůvodněné intuice vědců, kteř́ jsou ve filosofii vědy amatéry, nemohou sloužit jako základ pro formulování jakékoli seriózní teorie. Domnívají se, že vědci nejsou v oblasti filosofie vědy kompetentní, protože se zabývají jen malou výsečí lidského poznání, a jejich intuice o problémech vědecké metodologie jsou dosti irelevantní. To ale obecně neplatí, protože vědci bud' disponují explicitními znalostmi filosofického diskurzu vědě, nebo o těchto věcech tak jako tak uvažují implicitně při své práci, byt' ne vždy v pojmech používaných filosofy vědy, jak ukázal například kvalitativní x-phi výzkum objektivity př́rodních věd (Jedlička - Paitlová 2019). Stejně tak by bylo možné namítnout, že filosofové vědy mohou být nekompetentní v nějaké vědecké disciplíně, a proto jejich výpovědi o ní (nebo o vědě obecně) jsou irelevantní.

Analýza empiricky a experimentálně získaných dat může v duchu Popperovy transcendentální teze sloužit jako kritický test tradičních filosofických teorií, může pomoci identifikovat nové anebo aktuální fenomény, které by filosofie vědy měla zahrnout do svého zkoumání, popřípadě může být inspirací pro nové teorie. Jak již bylo řečeno, x-phi tak může přispět k přiblížení se skutečnosti a aktuální vědecké praxi, i když na druhou stranu nelze výsledky filosofických experimentů přeceňovat. Např́klad Kaupinnen kritizuje zmíněné dotazníkové průzkumy, které „nás mohou informovat pouze o povrchních intuicích, které nám ale

\footnotetext{
Viz (Kaupinnen 2007).

Srov. (Nadelhoffer \& Nahmias 2007, 125).

3 Ačkoli pak x-phi zároveň čelí v první rovině problému reprodukovatelnosti výsledků jako ostatní empirické vědy, srov. (Cova 2018). Ve druhé (filosofické) rovině čelí problému indukce.
} 
nepomáhají v projektu zjišt’ování lidových konceptů“ (Kaupinnen 2007, 101). Odpověd' respondenta totiž nemusí vždy odhalit, co je intencí jeho konceptu, pokud to vyplývá z nějakého jiného faktoru, jako je nepozornost nebo pragmatické úvahy, které průzkumy nekontrolují. $V$ tomto případě však lze s Kaupinnenem polemizovat, nebot’ záměrem x-phi není nahradit tradiční filosofické metody, ale obohatit je pochopením toho, jak se vytvářejí a ustanovují jednotlivé intuice a koncepty ve filosofii a jejích jednotlivých disciplínách. ${ }^{14}$

\section{Závěr}

V této stati jsme argumentovali, že v kontextu naturalizace filosofie se postupně rozšířilo spektrum př́istupů, díky nimž může být objektivní poznání uchopeno. Ukázali jsme, že původní Descartův př́ístup byl ryze spekulativní, nebot' objektivní byla podle něj především pravdivá (ale neempirická) boží substance, případně abstraktní rozumové ideje. Kant učinil významný krok směrem k empirii (ač stále spekulativním způsobem), když za objektivní označil takové poznání, které je na jedné straně a priori určené subjektem a zároveň se vztahuje k empirickému objektu. Později pak Popper kromě vztahu k objektu vytkl pro objektivní poznání nutnost intersubjektivního testování a v rámci své „transcendentální teze“ požadoval, aby se filosofie (vědy) vztahovala k empirickým vědám tak, jak se tyto vztahují ke zkušenosti. Quine chápal objektivitu ve smyslu intersubjektivního jazykového zvěcňování objektů a zároveň explicitně vyslovil požadavek naturalizace filosofie. Ten mimo jiné přijal Bloor, který ještě více zdůraznil sociální charakter objektivity.

Za vrchol naturalizace filosofie jsme pak označili experimentálně filosofický přístup, který „objektivizuje“ samotné filosofické bádání. Proč by měly být intuice filosofů privilegované oproti intuicím ostatních lidí, vědců nebo dalších skupin? A jsou snad „epistemicky hodnotnější než intuice ostatních? Domníváme se, že ne, a to zakládá nárok na jejich empirické zkoumání, které osvětluje mnohé o jejich vzniku - např́klad to, že mohou záviset nikoliv na apriorních předpokladech a logickém rozvažování, ale na zcela „přízemních“ vlivech (jako je ekonomický a sociální status, nebo kultura, v níž se filosofové či filosofky pohybují). Proto považujeme tento typ bádání ve filosofii za cenný, legitimní a v zásadě komplementární (tedy nikoliv vylučující) vůči existujícím spekulativním přístupům. Podobný argument, používaný současnými experimentálními filosofy, ostatně není

14 K hlubšímu ověření dotazníkových průzkumů proto slouží experimenty s morálními dilematy. 
nový a vznesl ho již Arne Naess, který ze stejných pozic kritizoval spekulativní charakter logického empirismu. ${ }^{15}$

\section{Literatúra:}

BAKER, M. (2016): 1,500 Scientists Lift the Lid on Reproducibility. In: Nature, 533 (7604), $452-54$.

BENDA, L. (2011): Historiografická metoda Thomase Kuhna a její význam z hlediska sociologie vědeckého poznání. In: Teorie vědy / Theory of Science 33 (3), $445-468$.

BLOOR, D. (1991): Knowledge and Social Imagery. Chicago and London: The University of Chicago Press.

COLLIER, A. (2003): In Defence of Objectivity and Other Essays. London and New York: Routledge.

COLLIN, F. (2011): Science Studies as Naturalized Philosophy. Dordrecht/ Heidelberg / London / New York: Springer.

COVA, F. - STRICKLAND, B. - ABATISTA, A. et al. (2018): Estimating the Reproducibility of Experimental Philosophy. In: Review of Philosophy and Psychology, published on-line: 14 June 2018, https://doi.org/10.1007/ s13164-018-0400-9.

DASTON, L. - GALISON, P. (2007): Objectivity. New York: Zone Books.

DESCARTES, R. (2003): Meditace o první filosofii (přeložili Petr Glombíček, Tomáš Marvan a Pavel Zavadil). Praha: OIKOYMENH.

GREENE, J. et al. (2004): The Neural Bases of Cognitive Conflict and Control in Moral Judgment. In: Neuron 44 (2), $389-400$.

GRUNDMANN, T. - HORVATH, J. - KIPPER, J. (2014): Die experimentelle Philosophie in der Diskussion. Berlin: Suhrkamp.

HOLZHEY, H. - RÖD, W. (2006): Filosofie 19. a 20. století II. Novokantovství, idealismus, realismus a fenomenologie. Praha: OIKOYMENH.

CHAPMAN, S. (2018): The Experimental and the Empirical: Arne Naess' Statistical Approach to Philosophy. In: British Journal for the History of Philosophy, 26 (5), $961-981$.

JEDLIČKA, P. - PAITLOVÁ, J. (2019): Objektivita přírodních věd pohledem experimentální filosofie. In: Teorie vědy / Theory of Science, 41(2), 229 - 258.

KANT, I. (2001): Kritika čistého rozumu (prekl. Jaromír Loužil ve spolupráci s Jiřím Chotašem a Ivanem Chvatíkem). Praha: OIKOYMENH.

KAUPPINEN, A. (2007): The Rise and Fall of Experimental Philosophy. In: Philosophical Explorations 10 (2), 95 - 118.

KEUTH, H. (1978): Realität und Wahrheit. Tübingen: Mohr Siebeck.

KNOBE, J. - NICHOLS, S. (2008). An Experimental Philosophy Manifesto. In: J. Knobe \& S. Nichols: Experimental Philosophy. New York: Oxford University Press, $3-14$.

KUHN, T. (2000): The Road Since Structure: Philosophical Essays, 1970 - 1993. Chicago and London: The University of Chicago Press.

15 Viz (Chapman 2018). 
NADELHOFFER, T. - NAHMIAS, E. (2007): The Past and Future of Experimental Philosophy. In: Philosophical Explorations 10 (2), 123 - 149.

NOZIK, R. (2001): Invariances. Cambridge (Massachusetts): Harvard University Press.

PEREGRIN, J. (2014): Kapitoly z analytické filosofie. Praha: Filosofia.

POPPER, K. (1989): Logik der Sozialwissenschaften. In: T. W. Adorno et alii: Positivismusstreit in der deutschen Soziologie. Frankfurt am Main: Luchterhand, $103-123$.

POPPER, K. (1994a): Objective Knowledge. Oxford: Clarendon Press.

POPPER, K. (1994b): Die beiden Grundprobleme der Erkenntnistheorie. Tübingen: Mohr Siebeck.

POPPER, K. (1997): Logika vědeckého zkoumání (prekl. Jiří Fiala). Praha: OIKOYMENH.

PRINZ, J. (2008): Empirical Philosophy and Experimental Philosophy. In: J. Knobe \& S. Nichols: Experimental Philosophy. New York: Oxford University Press, $189-208$.

QUINE, W. (1994): Hledání pravdy (přeložil Jaroslav Peregrin). Praha: Herrmann a synové.

QUINE, W. (2006): Vybrané články k ontologii a epistemologii (prekl. kolektiv autorů) Plzeň: Západočeská univerzita.

RESCHER, N. (1997): Objectivity: The Obligations of Impersonal Reason. Notre Dame and London: University of Notre Dame Press.

SCHLICK, M. (2008). Gesamtausgabe. Band I/6. Wien / New York: Springer.

SOSA, E. (2007): Experimental Philosophy and Philosophical Intuition. In: Philosophical Studies: An International Journal for Philosophy in the Analytic Tradition 132 (1), 99 - 107.

ZIMMER, R. - MORGENSTERN, M., eds. (2011): Gespräche mit Hans Albert. Münster: LIT Verlag.

Stat' vznikla v rámci projektu „Objektivita: Experimentální př́stup k tradičnímu filosofickému problému“ (GAČR č. 18-08239S).

Mgr. Jitka Paitlová, Ph.D.

Katedra filozofie FF ZČU

Sedláčkova 19

30614 Plzeň, CZ

paitlova@kfi.zcu.cz

PhDr. Petr Jedlička

Katedra filozofie FF ZČU

Sedláčkova 19

30614 Plzeň, CZ

pjedlick@kfi.zcu.cz 